\title{
DETERMINING THE EFFECTS OF WILTING TIME ON SOME QUALITY PARAMETERS IN SOYBEAN HAYLAGE
}

\author{
A. Korhan SAHAR ${ }^{*}$, Yasemin VURARAK ${ }^{1}$, Plnar CUBUKCU ${ }^{1}$, Hatice YUCEL ${ }^{1}$ \\ ${ }^{l}$ Eastern Mediterranean Agricultural Research Institute, Adana, TURKEY \\ *Corresponding author: akorhansahar@gmail.com
}

Received: 20.02 .2019

\begin{abstract}
This study was carried out in Adana province for two years $(2016,2017)$ to determine the effect of wilting times on soybean haylage. All of the harvests were made using the conditioner mower in the development phase of soybean R6. The harvested soybean forage was allowed to wilt for $\mathbf{4}$ different wilting times under field conditions. Small-scale haylage bales of $40-50 \mathrm{~kg}$ weight were prepared for each subject. These bales were wrapping with 4 layers of polyethylene material without any additives and storage to ferment for 60 days. The wilting time was based on crude protein, acid detergent fiber, neutral detergent fiber, digestible dry matter, dry matter consumption and relative feed value was found to have an effective statistical significance at $1 \%$ $(\mathbf{p}<0.01)$ significance level. Furthermore, it was determined that wilting time was effective at $1 \%(p<0.01)$ significance level on haylage bales weight, dry matter content, $\mathrm{pH}$ and haylage bales density. As a result, it was determined that the highest value in terms of relative feed value were obtained by wrapping the haylage after $18 \mathrm{~h}$ - $22 \mathrm{~h}$ of wilting. In addition, it was determined that in terms of crude protein, roughage quality was reduced by $31.4 \%$ on average with $80 \mathrm{~h}$ wilting compared with the other applications.
\end{abstract}

Keywords: Duration of wilted, Legume forages, Process, Relative feed value, Roughage

\section{INTRODUCTION}

One of the main problems encountered in dairy cattle breeding are the various difficulties experienced in obtaining roughage producted from high-leguminous feed crops. Rough feeds made from soybean (Glycine max $L$. Merr.) have attracted attention in recent years as a valuable protein source that can be used as an alternative to very expensive protein sources in ruminant nutrition (Mccandlish, 2017). Corn ensilage with traditional methods is widely used as a source of roughage as is the case in countries throughout the world. The basic reasons for widely of corn for source silage purposes are the high yield, the ease with which it can be ensiled and its high energy value as a feed source (Carpic1 et al., 2010). However, when the sources of carbon emission in agriculture are examined, it has been determined that the carbon emission generated during corn silage production is high (Sezer, 2014). In addition, due to the low protein content of maize silage, different rations of high protein content are needed. Geren and Kavut (2015) emphasized that any attempt to benefit from new forage crop production alternatives are of vital importance the Mediterranean conditions of west and south part of Turkey which represents many favorable factors for crop growth. Soybean can be planting as second crops after grain harvest in Mediterranean climate conditions (Ilker, 2017).
In addition to human nutrition, the green parts and seed of soybean, a member of the legume family, are among valuable nutrients as animal feed. Roughage, the importance of which increases in ruminant nutrition in Turkey every day, is made in different ways and added to rations. Soybean silage has started to be mixed with maize silage albeit not extensively because of its high protein content. However, the use of pure soybean is almost negligible. One of the reasons for this is that because the buffer capacities of forage legume like the soybean makes it harder to silo compared with poaceae forage (Dewhurst et al., 2003). It is recommended that forage legumes are wilted before storage or that some additives are added to resolve this problem (Uygur, 2018). Taylor et al. (2017) use non additive soybean, soybean mixture and alfalfa silages to test digestibility in heifer ratios and found that the digestibility of non additive soybean silage was better than the other roughage used. According to the researchers, the potential for non additive soybean silage as roughage is rather high. In their study of soybean silage Rosal et al. (2018) compared soybean silage with and without additives in terms of some parameters. As a result, it was determined that the population of Lactic Acid (LA) Bacteria from day 1 to day 56 of fermentation gradually increased in subjects without additives. Some additives must be mixed into traditional silages in certain amounts to protect the quality of forage legumes. However, this leads to an increase in unit costs. In recent years some 
studies report that it is possible to maintain haylage, one of the roughages the use of which has increased as an alternative to traditional silage without using additives with the legume or wheat forages (Yaman and Sonmezler, 2011; Franco et al., 2018).

Haylage, which is one of the roughage techniques, is prepared by compressing harvested fodder plants into bales and then leaving them in an airless medium by wrapping them in polyethylene plastic and the dry matter content is desired to be $40-60 \%$. It has been reported that these roughages are more valuable feeds compared to dry grass and traditional silage in terms of dry matter and nutrient losses (Schroeder, 2004). In haylage tecniques, the product is either wilted or allowed to complete its development until it reaches the desired Dry matter (DM) content level. However, it is known that during the time that the content of DM is expected to reach the desired level a decrease in the nutrient, digestibility and some quality values incur with the aging of the plant (Buxton, 1986; Christen et al., 1990). Instead of this process, the producer has the possibility of harvesting the highest protein ratio of the plant in the period when the DM ratio is low with the wilting process. The average increase in the DM level is about $1 \%$ per hour per day during wilting. Baling of fresh plants with $75-85 \%$ moisture content without wilting causes abnormal low temperature fermentation, which results in increased moisture content and undesirable production of clostridial organisms leading to ) increased Butyric Acid (BA) and the degradation of silage. In their study O'Kiely et al. (2002) harvested a lolium perenne with a conditioner harvesting machine and storage it to wilt for 24, 48 and 72 hours. At the end of 295 days of fermentation silage which had been wilted at a minimum revealed Crude Protein (CP) and digestible DM ratios of $171,744 \mathrm{~g} \mathrm{~kg}^{-1}$ respectively, the values for medium wilted silages was $172,754 \mathrm{~g} \mathrm{~kg}^{-1}$ while the values for highly wilted silage were measured as $171,733 \mathrm{~g} \mathrm{~kg}^{-1}$. Among all the values, those after 47 hours of wilting gave the best results. Muller et al. (2007) carried out a study in which they used and harvested three different fodder plants mixed at different ratios and harvested the product with a conditioned harvesting machine. After harvesting, they were wilted until three different DM contents (350, 550 and $700 \mathrm{~g} \mathrm{DM} \mathrm{kg}^{-1}$ ) were obtained. The obtained silage and haylage was storaged to ferment for 2 different periods ( 2 and 14 months). At the end of the study, it was determined that the fermentation of the subjects compared to traditional silage was limited. The CP rates in DM were determined as 108, 104, $98 \mathrm{~g}$ $\mathrm{kg}^{-1}$ in silage and low-high DM content, respectively. It was determined that the $\mathrm{CP}$ rate in haylage decreased as the content of DM increased. In traditional silage, the $\mathrm{pH}$ levels were found to be 4.8 and 4.5 for 2 and 14 months respectively and in the low DM content haylage the contents were 5.62 and 5.48 for 2 and 14 months respectively and they increased up to 6.84 and 6.59 in high DM content haylage. In their study Yaman and Sonmezler (2011) produced haylage silage with different plant materials and compared them in terms of dry grass roughage quality parameters and determined that the quality of the haylage had superior qualities compared to other subjects. In her study, Vurarak (2016) harvested two different fodder crop mixtures with different harvesting machines and storage them in three different ways (traditional silage, haylage and dry hay). At the end of the study, it was determined that coarse fodder which is storage as haylage in both mixtures is higher compared to the other Relative Feed Value (RFV) fodder production methods.

The application of the haylage method in soybean which is a legume plant is important in providing an alternative to fill the gap in quality roughage. Touno et al. (2014) carried out a study with soybeans and Italian ryegrass without using any additives and compared the separately manufactured silages in terms of protein, digestibility and nitrogen balance of wheat bran. At the end of the study, it was determined that soybean silage was superior to other feeds in terms of protein content and CP content insoluble in Acid Detergent Fiber (ADF). Furthermore, it was determined that phytoestrogen content, which would make soybean silage have a negative affect on reproduction, was below the limit value, ie it had no negative effect on reproduction. It has been reported that soybean haylage has no negative effect on the digestion and nitrogen balance in sheep nutrition and therefore it could be used as an alternative protein source to wheat bran in the diets of small ruminants. In another study, it was reported that soybean feed could be successfully used in ruminant feeding with energy and digestible nutrients which can be used because of the lesser effect of methane emissions on the environment (Lima et al., 2013). In addition, it is emphasized by researchers that forage soybean has an important place in leguminous feeds with its high nutritional value and low cost (Vargas et al., 2008; Chang et al., 2012; Drewnoski et al., 2012; Mccandlish, 2017).

This study focuses on determining the effects of wilting time on quality in non additives soybean haylage.

\section{MATERIALS AND METHODS}

\section{Materials}

The trials were carried out in the Eastern Mediterranean Agricultural Research Institute (EMARI), Dogankent location in Adana province located in the Mediterranean Climate Zone. The trial location is $36^{\circ} 85^{\prime}$ 'north latitude, $35^{\circ} 34^{\prime}$ 'east longitude and the elevation from sea level is $12 \mathrm{~m}$. Some climate data are given in Table 1 for the two years of trials conducted in 2016 and 2017.

Yesilsoy, soybean variety was used in the trial as plant material. This variety has a long oval leaf and semiupright growth in the IV. maturity group. Plant height average ranges between $110-150 \mathrm{~cm}$, green grass yield between $40000-56000 \mathrm{~kg} \mathrm{ha}^{-1}$, dry hay yield between 12 000-20 $000 \mathrm{~kg} \mathrm{ha}^{-1}$ and seed yield between $3500-4000 \mathrm{~kg}$ $\mathrm{ha}^{-1}$ (EMARI, 2018). 
Table 1. Climate data for the experiment area (2016 - 2017)

\begin{tabular}{|c|c|c|c|c|c|c|c|c|c|c|c|c|}
\hline \multirow[b]{3}{*}{ Months } & \multicolumn{6}{|c|}{ Temperature ${ }^{\circ} \mathrm{C}$} & \multicolumn{6}{|c|}{ Other climate data } \\
\hline & \multicolumn{2}{|c|}{ Max. } & \multicolumn{2}{|c|}{ Ave. } & \multicolumn{2}{|c|}{ Min. } & \multicolumn{2}{|c|}{ Humidity $\%$} & \multicolumn{2}{|c|}{ Wind $\mathrm{km} \mathrm{h}^{-1}$} & \multicolumn{2}{|c|}{ Precipitation $\mathrm{mm}$} \\
\hline & 2016 & 2017 & 2016 & 2017 & 2016 & 2017 & 2016 & 2017 & 2016 & 2017 & 2016 & 2017 \\
\hline April & 33 & 35 & 19 & 23 & 6 & 12 & 61 & 63 & 10 & 11 & 30.22 & 38.87 \\
\hline May & 33 & 33 & 21 & 21 & 11 & 11 & 69 & 70 & 10 & 10 & 20.56 & 109.7 \\
\hline June & 41 & 37 & 26 & 25 & 17 & 14 & 64 & 68 & 9 & 9 & 4.57 & 28.96 \\
\hline July & 39 & 43 & 29 & 29 & 20 & 19 & 65 & 63 & 9 & 10 & 0 & 0 \\
\hline August & 39 & 43 & 29 & 29 & 20 & 21 & 68 & 66 & 9 & 9 & 9.91 & 0 \\
\hline September & 36 & 38 & 26 & 26 & 11 & 16 & 60 & 64 & 10.5 & 9 & 17.27 & 1.05 \\
\hline October & 35 & 32 & 23 & 22 & 12 & 12 & 51 & 51 & 10 & 10 & 1.02 & 28.95 \\
\hline
\end{tabular}

Source: http://mobile.wunderground.com/history/airport/LTAG/2017/10/31/DailyHistory.html,

http://mobile.wunderground.com/history/airport/LTAG/2016/10/31/DailyHistory.html

\section{Methods}

The experiment was designed as a randomized plot design with three replications. The trial subjects were determined as 4 different wilting times, namely systems $\left(\mathrm{S}_{1}: 1 \mathrm{~h}, \mathrm{~S}_{2}: 18 \mathrm{~h}, \mathrm{~S}_{3}: 22 \mathrm{~h}\right.$ and $\left.\mathrm{S}_{4}: 80 \mathrm{~h}\right)$. At the end of the wilting time, the products were wrapped with 4 layers of polyethylene (PE) wrapping material (the thickness of the PE material was $0.025 \mathrm{~mm}$, its width $25 \mathrm{~cm}$, white in color with $70 \%$ elasticity). During the two years of the experiment, planting was done in the third week of June under second crop conditions using $70 \mathrm{~kg} \mathrm{ha}^{-1}$ seed. With the planting, $30 \mathrm{~kg} \mathrm{ha}^{-1} \mathrm{~N}, 70 \mathrm{~kg} \mathrm{ha}^{-1} \mathrm{P}_{2} \mathrm{O}_{5}$ and $100 \mathrm{~kg} \mathrm{ha}^{-1}$ $\mathrm{K}_{2} \mathrm{O}$ fertilizer were used and the seeds were inoculated with Bradyrhizobium japonicum bacteria before planting. Individual plots consisted of 4 rows $50 \mathrm{~m}$ long and $70 \mathrm{~cm}$ apart. The seed were sown in line pneumatic seed machine on second week of june and with $70 \times 5 \mathrm{~cm}$ distance in two year. Two manual hoeings and one tractor aided hoeing was carried out during the whole production season. After planting, the experiments were irrigated with 4-times furrow irrigation prior to flowering, full bloom and full pod stage. Insecticide has been applied once against white fly and thripe. Harvest time for the trials was second week of August in first year and first week of August in second year taking into account the maximum seed formation period of R6 period reported by Sahar (2017). A conditioner mower capable of a working width of $240 \mathrm{~cm}$ (Kuhn), a baler (RB50) for haylage bales making, and a bale wrapping machine (RS50M) for wrapping were used for the harvests.

The resulting haylage bales were storaged to ferment for 60 days and subsequently opened according to the subjects and sampled these samples were dried in the oven at $78^{\circ} \mathrm{C}$ for 48 hours and ground $(\leq 0.2 \mathrm{~mm})$. Bales weight and density of haylage according to subjects (Vurarak, 2016), DM \% (AOAC, 1990), pH (Chen, 1997), nitrogen content was determined by the Kjeldahl method and the determined nitrogen was multiplied by $6.25 \% \mathrm{CP}$
(AOAC, 1990), ADF \%, NDF \% (Van Soest et al., 1991), digestible DM \%, dry matter consumption DMC \% and RFV (Mayouf and Arbounche, 2014) and calculated as indicated in literature. The two-year data obtained from the study was subjected to variance analysis by statistical package program. Multiple comparisons according to 'LSMeans student's t' test was carried out for parameters with $F$ values at a significance level of $5 \%$ significance level of F-parameters.

\section{RESULTS AND DISCUSSION}

According to the two-year combined variance analysis, it was determined that wilting times (S) had a statistical impact on haylage bales weight $(\mathrm{p}<0.01)$, haylage bales density ( $\mathrm{p}<0.01), \mathrm{pH}(\mathrm{p}<0.01)$ and DM $(\mathrm{p}<0.01)$ (Table 2 ). It has been determined that haylage bale weight decreases at a rate of $49.4 \%$ as the wilting times progressed from $1 \mathrm{~h}$ to $80 \mathrm{~h}$ after harvest. The loss in bale weight with between $1 \mathrm{~h}$ and $18 \mathrm{~h}$ of wilting was determined as $15 \%$, while wilting between $1 \mathrm{~h}$ and $22 \mathrm{~h}$ incurred a weight loss of $32.7 \%$. This shows that there is an average weight loss of $0.89 \%-1.56 \%$ per hour. When the subjects were examined in terms of bale density, it turned out that the subjects changed in parallel with the bale weight.

It was determined that the DM content was affected by the test wilting times and the ratio of DM increased by $137.8 \%$ between $1 \mathrm{~h}$ and $80 \mathrm{~h}$. This shows that the DM content increased by $0.68 \%-1.75 \%$ on average every hour. Likewise, Polak and Jancovo (2006) carried out a study in which they harvested grass and mixed fodder crops and left them to wilt and measured DM content for 2 days in the morning and in the afternoon for a total of 4 times. They reported that DM content increased with the increase of wilting time. There are also drawbacks to over wilting. The feed, which has less moisture than the recommended moisture content, warms up and undergoes loss at harvest and during storage and the digestible amounts are also reduced (Sullivan and McKinlay, 1998) 
Table 2. Changes in the DM, pH, bale weight and density in soybean haylage according to the duration of wilting

\begin{tabular}{|c|c|c|c|c|c|c|c|c|c|c|c|c|}
\hline \multirow{2}{*}{$\begin{array}{l}\text { Varianc } \\
\text { e source }\end{array}$} & \multicolumn{3}{|c|}{ Bales weight $\left(\mathrm{kg} \mathrm{bale}^{-1}\right)$} & \multicolumn{3}{|c|}{ DM (\%) } & \multicolumn{3}{|c|}{ pH } & \multicolumn{3}{|c|}{ Density $\left(\mathrm{kg} \mathrm{m}^{-3}\right)$} \\
\hline & 2016 & 2017 & Ave. & 2016 & 2017 & Ave. & 2016 & 2017 & Ave. & 2016 & 2017 & Ave. \\
\hline $\mathbf{S}_{1}$ & $46.72^{\mathrm{a}}$ & $43.00^{\mathrm{a}}$ & $44.86^{a}$ & $27.63^{\mathrm{c}}$ & $26.91^{\mathrm{c}}$ & $27.27^{c}$ & $4.02^{\mathrm{b}}$ & $5.02^{\mathrm{c}}$ & $4.52^{b}$ & $401.84^{\mathrm{a}}$ & $369.82^{\mathrm{a}}$ & $385.83^{a}$ \\
\hline $\mathbf{S}_{2}$ & $46.18^{\mathrm{a}}$ & $30.08^{\mathrm{b}}$ & $38.13^{b}$ & $31.26^{\mathrm{bc}}$ & $29.53^{\mathrm{c}}$ & $30.39^{c}$ & $3.38^{\mathrm{b}}$ & $5.44^{\mathrm{b}}$ & $4.41^{b}$ & $397.14^{\mathrm{a}}$ & $258.71^{\mathrm{b}}$ & $327.93^{b}$ \\
\hline $\mathbf{S}_{3}$ & $31.47^{\mathrm{b}}$ & $28.89^{\mathrm{b}}$ & 30.18 & $36.80^{\mathrm{b}}$ & $38.25^{\mathrm{b}}$ & $37.52^{\mathrm{b}}$ & $3.69^{\mathrm{b}}$ & $5.18 b^{c}$ & $4.43^{b}$ & $270.67^{b}$ & $248.48^{b}$ & $259.57^{c}$ \\
\hline $\mathbf{S}_{4}$ & $21.58^{\mathrm{c}}$ & $23.88^{\mathrm{b}}$ & $22.73^{d}$ & $68.26^{\mathrm{a}}$ & $61.48^{\mathrm{a}}$ & $64.87^{\mathrm{a}}$ & $4.99^{\mathrm{a}}$ & $5.90^{\mathrm{a}}$ & $5.44^{\mathrm{a}}$ & $185.64^{\mathrm{c}}$ & $205.42^{\mathrm{b}}$ & $195.53^{d}$ \\
\hline LSD $_{.05}$ & 1.31 & 7.83 & 5.55 & 6.92 & 7.12 & 4.42 & 0.81 & 0.38 & 0.40 & 84.05 & 67.36 & 47.89 \\
\hline $\mathrm{CV}(\%)$ & 13.4 & 12.4 & 13.0 & 8.4 & 9.1 & 8.7 & 10.1 & 3.5 & 6.8 & 13.4 & 12.4 & 13.0 \\
\hline \multicolumn{13}{|c|}{ p value } \\
\hline $\mathbf{Y}$ & & & $0.0170^{*}$ & & & $0.2015^{\mathrm{ns}}$ & & & $\underset{*}{<0.0001^{*}}$ & & & $0^{0.0179}{ }^{*}$ \\
\hline $\mathbf{S}$ & $\underset{*}{0.0019^{*}}$ & $\underset{*}{0.005^{*}}$ & $\underset{*}{<0.0001^{*}}$ & $\underset{*}{<.0001^{*}}$ & $\underset{*}{<.0001^{*}}$ & $<\underset{*}{<0001}{ }^{*}$ & $\underset{*}{0.0136}$ & $\underset{*}{0.0065^{*}}$ & $0.0003^{* *}$ & $0.0019^{*}$ & $\underset{*}{0.0005^{*}}$ & $\underset{*}{<0.0001^{*}}$ \\
\hline $\mathbf{Y} \times \mathbf{S}$ & & & $0.0222^{*}$ & & & $0.2730^{\text {ns }}$ & & & 0.0323 $^{*}$ & & & $0.0220^{*}$ \\
\hline
\end{tabular}

In terms of $\mathrm{pH}$ value in soybean haylage it was reported that $1 \mathrm{~h}, 18 \mathrm{~h}$ and $22 \mathrm{~h}$ wilting times were in the same statistical group, the lowest $\mathrm{pH}$ value was found to be 4.41 with $18 \mathrm{~h}$ wilting. It was determined that the average $\mathrm{pH}$ value increased up to 5.44 and DM content up to $64.87 \%$ with $80 \mathrm{~h}$ of wilting. The content of DM is thought to show a parallel change with the $\mathrm{pH}$ value. Orosz et al. (2008) obtained a similar result in a study of clover after harvesting and wilting clover for $4 \mathrm{~h}$ and $12 \mathrm{~h}$ and determined that the $\mathrm{pH}$ values of haylage wilted for $4 \mathrm{~h}$ were less than the values of the other subject. The researchers reported that $\mathrm{pH}$ values increased with the wilting time.

According to variance analysis, it was determined that the $\mathrm{CP}, \mathrm{ADF}$ and neutral detergent fiber (NDF) values of the subjects were affected with a $1 \%$ ( $\mathrm{p}<0.01)$ significance level by the wilting times (Table 3). When the $\mathrm{CP}$ values of haylage was examined according to the subjects, it was determined that the $\mathrm{CP}$ rate was statistically affected with $1 \mathrm{~h}, 18 \mathrm{~h}$ and $22 \mathrm{~h}$ wilting times and they were in the same group but the highest $\mathrm{CP}$ value was obtained with $1 \mathrm{~h}$ of wilting. While the average $\mathrm{CP}$ rate obtained with $1 \mathrm{~h}, 18 \mathrm{~h}$ and $22 \mathrm{~h}$ of wilting was $12.54 \%$, it was determined that this value decreased by $31.42 \%$ and decreased down to $8.6 \%$ with $80 \mathrm{~h}$ of wilting. It is believed that with the increase in the amount of DM and increased leaf losses reduce the amount of $\mathrm{CP}$ during baling. Similarly, in their study Muller et al. (2007) reported that $\mathrm{CP}$ content decreased with the increase of wilting time in three different fodder crops. Furthermore, in their study, they reported that albeit different, the ratio of $\mathrm{pH}$ increased to $5.48-6.84$ in each of the three fodder crops, as the amount of DM increased. In their study, Franco et al. (2018) cut and wilted alfalfa and meadow grass for $4 \mathrm{~h}$ and $24 \mathrm{~h}$ and examined the CP contents of the obtained silage liquid. It was reported that the CP content of the liquid from the silages wilted for $4 \mathrm{~h}$ were almost 2 times more than the other subject and $4 \mathrm{~h}$ of wilting was recommended for traditional silage in Finnish conditions.

Table 3. Change of $\mathrm{CP}, \mathrm{ADF}$ and NDF values of soybean haylage according to the duration of wilting (\%)

\begin{tabular}{|c|c|c|c|c|c|c|c|c|c|}
\hline \multirow{2}{*}{ Variance source } & \multicolumn{3}{|c|}{ CP } & \multicolumn{3}{|c|}{ ADF } & \multicolumn{3}{|c|}{ NDF } \\
\hline & 2016 & 2017 & Ave. & 2016 & 2017 & Ave. & 2016 & 2017 & Ave. \\
\hline $\mathbf{S}_{1}$ & $14.19^{\mathrm{a}}$ & 11.67 & $12.93^{a}$ & $40.47^{\mathrm{a}}$ & $43.68^{\mathrm{a}}$ & $42.07^{\mathrm{a}}$ & $58.70^{\mathrm{a}}$ & $54.22^{\mathrm{a}}$ & $56.46^{\mathrm{a}}$ \\
\hline $\mathbf{S}_{2}$ & $12.83 \mathrm{a}^{\mathrm{b}}$ & 13.25 & $12.20^{\mathrm{a}}$ & $37.64^{\mathrm{ab}}$ & $40.78^{b}$ & $\mathbf{3 8 . 0 0}^{\mathrm{b}}$ & $48.94^{\mathrm{c}}$ & $46.78^{b}$ & $47.86^{b}$ \\
\hline $\mathbf{S}_{3}$ & $11.15^{\mathrm{b}}$ & 12.15 & $12.49^{\mathrm{a}}$ & $35.22^{\mathrm{b}}$ & $39.85^{\mathrm{b}}$ & $38.74^{b}$ & $50.89^{\mathrm{bc}}$ & $47.71^{\mathrm{b}}$ & $49.30^{b}$ \\
\hline $\mathbf{S}_{4}$ & $6,78^{\mathrm{c}}$ & 10.42 & $8.60^{b}$ & $40.55^{\mathrm{a}}$ & $39.27^{b}$ & $39.91^{\mathrm{b}}$ & $55.46^{\mathrm{ab}}$ & $50.53^{\mathrm{ab}}$ & $53.00^{\mathrm{a}}$ \\
\hline LSD. 05 & 2.25 & - & 1.58 & 4.27 & 2.02 & 2.11 & 4.57 & 6.29 & 3.45 \\
\hline $\mathrm{CV}(\%)$ & 10.0 & 11.6 & 10.8 & 3.3 & 2.5 & 4.2 & 4.2 & 6.3 & 5.3 \\
\hline \multicolumn{10}{|c|}{ p value } \\
\hline $\begin{array}{c}\mathbf{Y} \\
\mathbf{S} \\
\mathbf{Y} \times \mathbf{S}\end{array}$ & $0.0009^{* *}$ & $0.194^{\text {ns }}$ & $\begin{array}{l}\mathrm{O.245}^{\text {ns }} \\
\mathrm{O.0002}^{* *} \\
\mathbf{0 . 0 0 5 3}^{* *}\end{array}$ & $0.063^{*}$ & $0.0075^{* *}$ & $\begin{array}{l}\mathrm{O.0042}^{* *} \\
\mathrm{O.0067}^{* *} \\
\mathrm{0.0286}^{*}\end{array}$ & $0.0074^{* *}$ & $0.097^{*}$ & $\begin{array}{l}0.0068^{* * *} \\
0^{* 0007^{* *}} \\
\mathbf{0 . 8 1 8 3}^{\text {ns }}\end{array}$ \\
\hline
\end{tabular}

${ }^{*} \mathrm{p}<0.05 ;{ }^{* *} \mathrm{p}<0.01$ Significant within error limits; ns: Not significant; S: Wilting time; $\mathrm{S}_{1}: 1 \mathrm{~h}, \mathrm{~S}_{2}: 18 \mathrm{~h}, \mathrm{~S}_{3}: 22 \mathrm{~h}, \mathrm{~S}_{4}: 80 \mathrm{~h} ; \mathrm{Y}:$ year; CP: Crude protein; ADF: Acid detergent fiber; NDF: Neuntral detergent fiber

It was determined that the subjects of $18 \mathrm{~h}, 22 \mathrm{~h}$ and $80 \mathrm{~h}$ wilting duration in soybean haylage were statistically in the same group in terms of ADF value and that ADF value decreased compared to the $1 \mathrm{~h}$ wilting period. In $\mathrm{NDF}$ value, $1 \mathrm{~h}$ and $80 \mathrm{~h}$ wilting times were in the same group and reached the highest value compared to the other subjects. Generally, dry matter intake is reduced when the percentage of NDF increases (Joachim and Jung, 1997).
Table 3 shows that subjects with low ADF and NDF values were obtained with $18 \mathrm{~h}$ and $22 \mathrm{~h}$ wilting times. In their study, Keles et al. (2009) wilted British turf for 24, 48 and 72 hours and left the resulting product to ferment for 295 days as bale silage. It was determined that the effect of wilting time on DM, digestible DM ratios and Raw Ash had a $1 \%$ significance level. 
According to variance analysis, it was determined that the significance level that wilting time subjects had on Digestible DM, DMC and RFV values was $1 \%$ (p <0.01). Statistically it was found that $18 \mathrm{~h}, 22 \mathrm{~h}$ and $80 \mathrm{~h}$ wilting times were in the same group and they had higher Digestible DM than $1 \mathrm{~h}$ wilting. However, Table 4 shows that the subject with the highest proportion of Digestible
$\mathrm{DM}$ is $59.9 \%$ with $18 \mathrm{~h}$. Statistically, it was determined that the wilting times from $1 \mathrm{~h}$ to $80 \mathrm{~h}$ and $18 \mathrm{~h}$ to $22 \mathrm{~h}$ were in the same group but the highest DMC values were obtained from $18 \mathrm{~h}$ and $22 \mathrm{~h}$ wilting period. Depending on the feed quality, the feeding behavior of animals, feed consumption, feed digestibility and its conversion into animal products varies (Van Soest, 1994).

Table 4. Changes in Digestible DM, DMC and RFV of soybean haylages according to wilting times

\begin{tabular}{|c|c|c|c|c|c|c|c|c|c|}
\hline \multirow{2}{*}{ Variance source } & \multicolumn{3}{|c|}{ (\%)Digestible DM } & \multicolumn{3}{|c|}{$(\%) \mathrm{DMC}$} & \multicolumn{3}{|c|}{ RFV } \\
\hline & 2016 & 2017 & Ave. & 2016 & 2017 & Ave. & 2016 & 2017 & Ave. \\
\hline $\mathbf{S}_{1}$ & 57.37 & $54.86^{\mathrm{b}}$ & $56.12^{b}$ & $2.04^{b}$ & 2.21 & $2.13^{b}$ & $90.94^{\mathrm{b}}$ & $94.23^{\mathrm{b}}$ & $92.58^{c}$ \\
\hline $\mathbf{S}_{2}$ & 61.46 & $57.12^{\mathrm{a}}$ & $59.29^{\mathrm{a}}$ & $2.45^{\mathrm{a}}$ & 2.56 & $2.51^{\mathrm{a}}$ & $116.81^{\mathrm{a}}$ & $113.83^{\mathrm{a}}$ & $115.32^{\mathrm{a}}$ \\
\hline $\mathbf{S}_{\mathbf{3}}$ & 59.57 & $57.12^{\mathrm{a}}$ & $58.71^{\mathrm{a}}$ & $2.35^{\mathrm{a}}$ & 2.52 & $2.44^{\mathrm{a}}$ & $108.98^{a}$ & $113.11^{\mathrm{a}}$ & $111.04^{a}$ \\
\hline $\mathbf{S}_{4}$ & 57.30 & $58.30^{\mathrm{a}}$ & $57.80^{\mathrm{a}}$ & $2.16^{\mathrm{b}}$ & 2.38 & $2.27^{b}$ & $96.38^{\mathrm{b}}$ & $107.59^{a}$ & $101.98^{b}$ \\
\hline LSD.05 & - & 1.58 & 1.62 & 0.18 & - & 0.15 & 10.56 & 12.39 & 7.19 \\
\hline $\operatorname{CV}(\%)$ & 2.8 & 1.38 & 2.2 & 4.0 & 6.1 & 5.1 & 5.1 & 5.8 & 7.2 \\
\hline \multicolumn{10}{|c|}{ p value } \\
\hline $\mathbf{Y}$ & & & $0.0042^{* *}$ & & & $0.0073^{* * *}$ & & & $0.1235^{n s}$ \\
\hline $\mathbf{S}$ & $0.063^{\mathrm{ns}}$ & $0.0075^{* *}$ & $0.0067^{* *}$ & $0.0067^{* *}$ & $0.1^{\mathrm{ns}}$ & $0.0009^{* *}$ & $0.0035^{* *}$ & $0.027^{*}$ & $<0.0001^{* *}$ \\
\hline
\end{tabular}

${ }^{*} \mathrm{p}<0.05 ; * * \mathrm{p}<0$. Significant within error limits; ns: Not significant; $\mathrm{S}_{1}: 1 \mathrm{~h}, \mathrm{~S}_{2}: 18 \mathrm{~h}, \mathrm{~S}_{3}: 22 \mathrm{~h}, \mathrm{~S}_{4}: 80 \mathrm{~h} ; \mathrm{Y}$ : Year; S: wilting time;

Digestible DM: Digestible dry matter; DMC: Dry matter consumption; RFV: Relative feed value; $88,9-(0,779 * \% \mathrm{ADF}) ; \% \mathrm{DMC}=120 / \% \mathrm{NDF} ; \mathrm{RFV}=((88.9-(0.779 \mathrm{x} \% \mathrm{ADF})) \mathrm{x}(120 / \% \mathrm{NDF}) / 1.29)$

According to the evaluations made for RFV, it was determined that the haylage obtained from a $1 \mathrm{~h}$ wilting period were the lowest in RFV and the highest RFV was found in the $18 \mathrm{~h}$ and $22 \mathrm{~h}$ wilting period. It was determined that on average, product wilted for $18 \mathrm{~h}$ or $22 \mathrm{~h}$ had a $22.26 \%$ higher RFV than the product wilted for $1 \mathrm{~h}$. The feed quality decreases as the relative feed value falls below 100 and increases when it rises (Redfearn et al., 2006).

The data obtained are consistent with the data reported in literature to a major degree. Spanghero et al. (2015) found that the $\mathrm{pH}$ value of traditional silages obtained from soybeans harvested in the R6 phase was $5.1, \mathrm{CP}$ value was $19.9 \%$, NDF and ADF values were $58.5 \%$ and $36.1 \%$, respectively. In his study, Sahar (2017) produced traditional silage in the R6 phase from Yeşilsoy soybean variety without wilting and without using additives. It was determined that the $\mathrm{pH}$ of silages left to fermet for 60 days was between 4.9-4.27, DM content was between 25.3$25.9 \%$, CP content was between $13.77-13.07 \%$, NDF and ADF contents were between $49.47-50.22 \%$ and 38.85 $44.30 \%$, respectively while DMC was between 2.42 2.40\%, Digestible DM ratio was between 58.62-54.37\% and RFV was between 110.25-100.75.

\section{CONCLUSION}

It has been concluded that the quality of small scale haylage roughage produced from non additives soybean is good. According to these results, it can be said that soybean haylage produced with additives can be used as an alternative to traditional silage.

It has been concluded that Mediterranean Climate Conditions are effective in obtaining the highest quality products in terms of RFV which is the ultimate target of harvesting plants in the R6 phase for soybean haylage and wilting them for $18 \mathrm{~h}-22 \mathrm{~h}$ without the use of any additives and storing them. Trying similar studies also in large-scale haylage bales is important in terms of confirming the same results.

\section{LITERATURE CITED}

AOAC. 1990. Association of official analytical chemists. Official Method of Analysis. 15 ${ }^{\text {th }}$. Ed Washington DC, USA, 66-68.

Buxton, D.R., J.S. Homstein. 1986. Cell-wall concentration and components in strstified canopies of alfalfa, birdsfood trefoil and red clover. Crop Sci. 29: 429-435.

Carpıc1, E.B., N. Celik, G. Bayram. 2010. Yield and quality of forage maize as influenced by plant density and nitrogen rate. Turk J. Field Crops. 15(2): 128-132.

Chang, S.R., C.H. Lu, H.S. Lur, F.H. Hsu. 2012. Forage yield, chemical contents, and silage quality of manure sybean. Agronomy Journal 104: 130-136.

Chen, V., M.R. Stoker, C.R. Wallance. 1997. Effect of enzymeinoculant sistems on preservation and nutritive value of haycrop and corn silage. Journal of Dairy Sci. 77: 501-512.

Christen, A.M., J.R. Seoane, G.D. Leroux. 1990. The nutritive value forsheep of quakckgrass and timothy hays harvested at two stage of growth. Journal of Animal Sci. 68: 3350-3359.

Dewhurst, R.J., W.J. Fisher, J.K.S. Tweed, R.J. Wilkins. 2003. Comparison of grass and legume silages forms production and production responses with different levels of concentrate. Journal of Dairy Sci. 86: 2598-2611.

Drewnoski, M.E. and M.H. Poore. 2012. Effects of suplemantation frequency on ruminalfermantation and digestion by steers fed medium-quality hay and supplemented with soybean hull and corn gluten feed blend. Journal of Animal Sci. 90: 881-891.

EMARI. 2018. Eastern mediterranean agricultural research institute plant variety catalogue. 
http://arastirma.tarim.gov.tr/cukurovataem/Sayfalar/EN/Ana Sayfa.aspx, (Accessed September 20, 2018)

Franco, M., T. Jalava, T. Stefanski, K. Kuoppala, P. Timonen, E. Winquist, M. Silka, M. Rinne. 2018. Effect of additives on silage quality and liquid-solid separation of timothy and red clover silages. Nordic Feed Sci. Conference, June 12-13, Finland. https://ibcfinland-fibin.directo.fi/@Bin/61b388d1f40749afcac49838b672690e/1 54279

6194/application/pdf/228198/Biorefinery_NFSC2018_Franco\%2 0et\%20al_PDF.pdf, (Accessed October 15, 2018)

Geren, H. and Y.T. Kavut. 2015. Efffect of different plant on yield and some silage quality characteritics of Giant King Grass (Pennisetum hybridum) under Mediterranean climatic conditions. Turk J. Field Crops. 20(1): 85-91.

Ilker, E. 2017. Performances of soybean (Glycine max (L.) Merr.) advences lines grown in second cropping under mediterrannean climatical conditions of western Turkey. Turk J. Field Crops. 22(1): 104-107.

Joachim, H. and G. Jung. 1997. Analysis of forage fiber and cell walls in ruminant nutrition. J. Nutr. 127: 810-813.

Keles, G., P. O'Kiely, J.J. Lenehan, P.D. Forristal. 2009. Conservation characteristics of baled grass silage differing in duration of wilting, bale density and number of layers of plastic stretch-film. Irish Journal of Agricultural and Food Research 48: 21-34.

Lima, R., M. Lourenco, R.F. Diaz, A. Castro, V. Fievez. 2010. Effect of combined ensiling of sorghum and soybean with or without molasses and lactobacilli on silage quality and in vitro rumen fermantation. Animal Feed Science and Technology 155(2):122-131.

Mc Candlish, A. C., E. Weaver, L. A. Lunde. 2017. Soybeans as a home-grown supplement for dairy cows. Bulletin. Vol (17): 204, http://lib.dr.iastate.edu/ bulletin /vol17/iss204/1, (Accessed September 22, 2018)

Mayouf, R. and F. Arbouche. 2014. Chemical composition and relative feed value of three mediterranean fodder shrubs. African Journal of Agricultural Research Vol 9 (8): 746-749.

Muller, C.E., T.M. Pauly, P. Uden. 2007. Storage of small bale silage and haylage- influence of storage period on fermentation variables and microbial composition. Grass and Forage Sci. 62: 274-283.

Orosz, S.Z., Z. Bellus, B. Kroll. 2008. Alfalfa bale-silage: a newforming technology. International Conference $13^{\text {th }}$. Forage Conservation. 3-5 September 2008 Nitra-Slovak Republic. pp: 166-168.

Polak, M. and M. Jancovo. 2006. Effectiveness of conditioning herbage at harvesting. $12^{\text {th }}$ International Symposium Forage Conservation, Brno, Czech Republic, April 3-5, 2006. pp: 186-189.

Rosal, L.O., K.G., Pereira, S.C. Ribeiro, F. Valadares, P.R. Cecon. 2018. Fermantation profile and microbial population in soybean silages with inoculant and powdered molasses. Arp. Bras. Med. Ved. Zootes., 70 (5): 1586-1594. http://dx.doi.org/10.1590/1678-4172-9500, (Accessed September 18, 2018)

Schroeder, J.W. 2004. Haylage and other fermented forages. NDSU Extension service, AS-1252, North Dakota State University Fargo.

Sezer, B. 2014. Karbon salınımı ve toprak yönetimi. www.tarim.gov.tr/ABOGM/Belgeler, (Accessed May, 2016)
Spanghero, M., C. Zanfi, M. Signor, D. Davanzo, V. Volpe, S. Venerus. 2015. Effects of plant vegetative stage and field drying time on chemical composition and in vitro ruminant degradation of forage soybean silage. Animal Feed Science and Technology 200: 102-106.

Sullivan, P. and J. McKinlay. 1998. Maintaining quality in large bale silage. Fact Sheet. Ontario Ministry of Agri. and Food. http://www.omafra.gov.on.ca/english/crops/facts/98069.htm. (Accessed December 12, 2018)

Sahar, A.K. 2017. The effect of silage additives on the silage quality and different harvesting stages on the herbage yield at soybean cultivars grown as second crop in Cukurova conditions. (2015-FBE-D218 Ph. D.Thesis, field Crops Sciences) $115 \mathrm{p}$, Van, TURKEY

O'Kiely, P., D.P. Forristal, K. Brady, K. Mcnamara, J.J. Lenehan, H. Fuller, J. Whelan. 2002. Baled silage conservation characteristics as influenced by forage dry matter concertration, bale density and the number of wraps of plastic wrap used. Improved Technologies for Baled Silage end of Project Report. Beef Production Series No: 50. Grange Researchcentre Dunsany Co. Meath, ISBN 1 841702919.

Redfearn, D., H. Zhang and J. Caddel. 2006. Forage quality interpretations. Oklahoma Cooperative Extension Service F2117.

http://pods.dasnr.okstate.edu/docushare/dsweb/get/Documen t-2557/F 2117web.pdf. (Accessed April 10.2019).

Taylor, E.G., P.J. Gunn, L.A. Horstman, R.L. Atkinson, K. Herron, K.D. Johnson, R.P. Lemenager. 2017. Evaluation of forage soybean, with and without pearl millet, as an alternative for beer replacement heifers. Translational Animal Sci. 1(2): 179-185.

Touno, E., M. Kaneko, S. Uozumi, H. Kawamoto, S. Deguchi. 2014. Evaluation of feding value of forage soybean sialge as a substitute for wheat bran in sheep. Animal Sci. J. 85: 146152.

Uygur, M. 2018. Forage crops for silage and the scince of silage making (Second print). Republic of Turkey Ministry of Agriculture and Forestry İzmir Directorate of Provincial Agriculture and Forestry. 177p, ISBN 978-605-2207-07-0

Yaman, S. and C. Sonmezler. 2011. Improving round bale silage production system. TUBITAK, Project Number: 105G086 (Final report).

Vargas-Bello-Perez, E., A.F. Mustafa, P. Seguin. 2008. Effects of feding forage sybean silage on milk production, nutrient digestion, and ruminant fermentation of loatating dairy cows. Journal of Dairy Sci. 91: 229-235.

Van Soest, P.J., J.D. Robertson, B.A. Lew1s. 1991. Methods for dietry fibre, neutral detergent fibre and non-starch polysaccharides in relation to animal nutrition. Journal of Dairy Sci. 74: 3583-3597.

Van Soest, P. J. 1994. Nutritional ecology of the ruminant $\left(2^{\text {nd }}\right.$ Ed.). p. 528. Cornell University Press. Ithaca, N.Y.

Vurarak, Y. 2016. Determination of effects of different harvesting and storage systems on machine management values and feed quality for some forage mixtures. Cukurova University Institute Of Natural and Applied Sciences Department of Agricultural Machinery and Technologies Engineering (Ph. D.Thesis ZF-2013-D29, Adana, TURKEY). 